\title{
Surgical repair of an olecranon fracture in a horse
}

\section{Reparação cirúrgica de fratura de olécrano em eqüino}

\author{
Antonio Cezar de Oliveira Dearo ${ }^{1 *}$; Joandes Henrique Fonteque ${ }^{2}$; \\ Fabrício Delgado Vidal'; Josmari Pirolo ${ }^{1}$
}

\begin{abstract}
Olecranon fractures are frequently encountered in horses especially in foals. External trauma due to kicks or falls is the most common cause of the fracture. Treatment modalities of olecranon fractures including prolonged stall rest and surgical reconstruction of the different types of fractures have been proposed with different outcomes. This article describes a successful surgical reconstruction of an olecranon fracture in an adult horse repaired with a dynamic compression plate. The horse regained complete soundness and performed his job normally for additional 7 years. Information regarding the history, clinical signs, diagnosis, surgical treatment and long-term prognosis is discussed and compared with the current literature.
\end{abstract}

Key words: Olecranon, ulna, osteosynthesis, fracture, horse

\section{Resumo}

As fraturas de olécrano ocorrem freqüentemente em eqüinos, especialmente em potros jovens. A causa mais comum da fratura relaciona-se ao trauma externo originado, principalmente, por coices ou quedas. Modalidades distintas de tratamento incluindo o repouso prolongado ou a reparação cirúrgica dos variados tipos de fratura têm sido executadas com diferentes resultados. Este trabalho tem por objetivo a descrição de um caso de fratura de olécrano em um eqüino adulto reparada cirurgicamente por meio de placa e parafusos ortopédicos. O animal apresentou recuperação plena da função locomotora desempenhando normalmente suas funções por mais 7 anos. Informações relativas ao histórico, sinais clínicos, diagnóstico, tratamento cirúrgico e prognóstico são discutidas e comparadas com a literatura.

Palavras-chave: Olecrano, ulna, osteossíntese, fratura, eqüino

1 Departamento de Clínicas Veterinárias - Universidade Estadual de Londrina - CCA - DCV - Londrina - PR. E-mail: dearoaco@uel.br

2 Departamento de Clínica e Patologia - UDESC - SC - Brasil

3 Large animal practitioner - SP - Brasil

* Corresponding author 


\section{Introduction}

Fractures of the ulna and olecranon are relatively common in horses and are primarily caused by external trauma (RICHARDSON, 1990; WATKINS, 2006). Clinical signs usually associated with olecranon fractures are manifested as an inability to bear weight on the injured limb and the classic "dropped elbow" stance. However, a small percentage of horses may still be able to bear weight on the limb with different grades of lameness (SWORN et al., 2006).

A number of fracture configurations have been described which include open, closed, articular, nonarticular, physeal, simple or comminuted with variable degrees of displacement and/or distraction (DONECKER; BRAMLAGE; GABEL, 1984; NIXON, 1996; FACKELMAN, 2000; STASHAK, 2002b).

Different surgical techniques to repair olecranon fractures in horses such as tension band plate (FRETZ, 1973;ANDERSON;ALLEN; DEBOWES, 1995; FACKELMAN, 2000; SWOR et al., 2003, 2006), tension band wiring including wires alone or in combination with pins or screws (MONIN, 1978; MARTIN et al., 1995; RICHARDSON, 2000) and hook plate fixation (MURRAY et al., 1996) have been reported. The majority of these reports have been described in North America and Europe and to date; it is unknown to the author's knowledge that detailed descriptions of surgically managed olecranon fractures in horses have been reported in Brazil.

Therefore, the purpose of this article is to describe a successful surgical repair of an olecranon fracture in an adult horse using the principles of tension band plate fixation.

\section{Case report}

A 5-year-old, $286 \mathrm{~kg}$, crossbreed stallion was presented to the State University of Londrina Veterinary Teaching Hospital (Londrina - Paraná
- Brazil) for evaluation of a left forelimb (LF) lameness of 15-days duration. According to the owner the horse had escaped from a small paddock over night and was found early in the morning showing signs of LF lameness. The horse was routinely used to draw a cart during gardening and general goods transportation services.

On physical examination the horse was bright, alert and responsive. All vital parameters were within normal limits. A grade 4 (range: 0 to 5) (STASHAK, 2002a) LF lameness was noticed along with a diffuse edematous swelling of the LF fetlock. At rest, the LF was kept in a semi-flexion position with the elbow joint "dropped". Closer examination of the elbow revealed a slight diffuse edematous swelling around the joint and a painful response upon palpation of the olecranon. Radiographic examination of the elbow joint revealed a complete, transverse, articular, moderately distracted, diaphyseal fracture of the olecranon (Fig. 1). Based on location and configuration of the fracture, as well as the expectations of the owner to fully recover the horse's previous function as a cart-puller, surgical correction of the fracture was recommended.

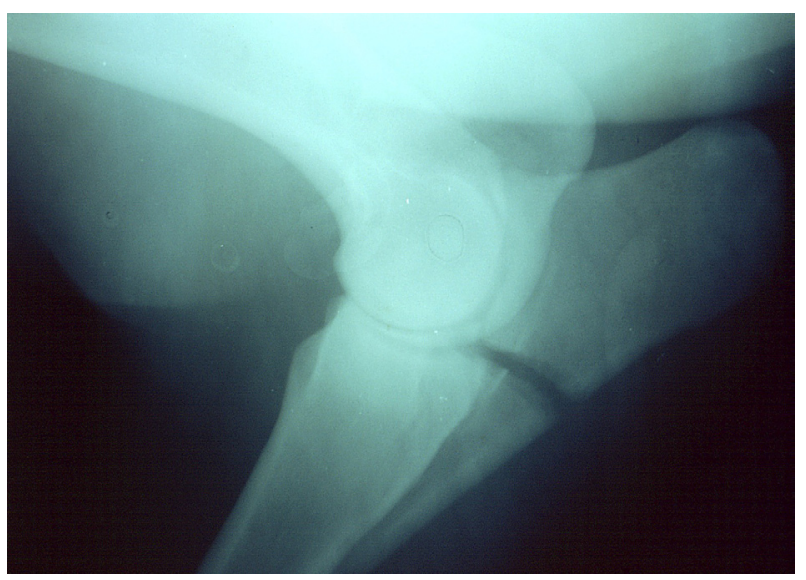

Figure 1. Lateral radiographic view of the elbow joint showing an articular fracture of the olecranon.

The horse was kept off feed overnight and an intravenous catheter was placed in the left jugular vein in the following morning. Preoperative antibiotics 
using a penicillin and streptomycin combination were administered intramuscularly. The horse was sedated with romifidine and induction of anesthesia was carried out with midazolam and thiopental. The horse was positioned in lateral recumbency with the affected limb uppermost. General anesthesia was maintained with halothane in a semi-closed circuit. After routine clipping, scrubbing and draping, the olecranon was surgically approached and the fracture site exposed as described by Milne and Turner (1987). Blood clots were removed and the fracture site was profusely lavaged with saline solution. Stabilization of the fracture was achieved by means of a 10-hole narrow, $4.5 \mathrm{~mm}$ dynamic compression plate (DCP) applied with $4.5 \mathrm{~mm}$, fully threaded cortical screws of variable lengths (Fig.2) using the principles of self-compression of the plate (NIXON; WATKINS; AUER, 1996). Complete and detailed description of the surgical technique can be found elsewhere (MCILWRAITH; ROBERTSON, 1998; WATKINS, 2006). Accurate anatomic reduction of the fracture could not be achieved resulting in a fracture gap.

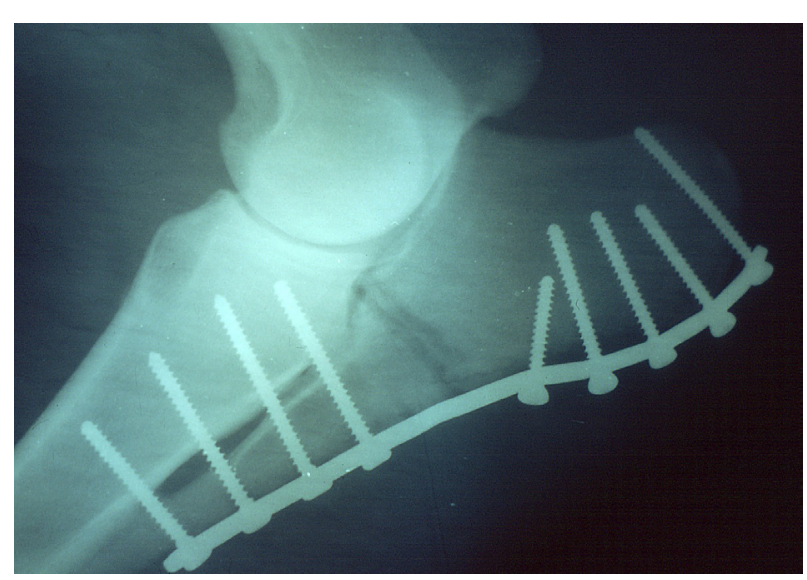

Figure 2. Lateral radiographic view of the elbow joint showing stabilization of the olecranon fracture with a $4.5 \mathrm{~mm}$, narrow, DCP.

Once plating was finished the soft tissues were lavaged with saline solution and closed in four separate layers covering the whole length of the plate. Deep fascia and muscular layers were closed with synthetic, multifilament, absorbable suture in a cruciate pattern followed by closure of the superficial fascia and subcutaneous tissue with synthetic, multifilament, absorbable suture in a simple continuous pattern. The skin incision was closed with synthetic, non-absorbable suture in a simple interrupted pattern. After suturing a stent bandage over the skin incision the general anesthesia was discontinued and the horse was removed to the recovery area. The horse had a stormy recovery characterized by episodes of anxiety, restlessness and premature attempts to stand up. When recovery was complete the horse was taken to the stall and water was left at will. Postoperatively, the horse was treated with penicillin and streptomycin combination, and phenylbutazone for 5 days. Physical examinations were performed twice a day. Laboratory data including hematology, fibrinogen and total plasma protein (TPP) were determined as needed. No relevant abnormalities on vital parameters were noticed throughout the postoperative period. The horse remained bright, alert and responsive. Periodical lameness evaluation revealed continuous improvement of the lameness status characterized by increased weight bearing on the operated limb. Feeding was gradually introduced which consisted of increasing amounts of coast cross hay offered in a daily basis. On day 5 and 6 postoperatively, the horse showed mild signs of abdominal pain. Physical examination revealed increased gastrointestinal sounds in all quadrants of the abdomen and diarrhea. Abdominal pain was successfully managed with butylscopolamine and hyoscine on day 5 and flunixim meglumine on day 6. No further signs of abdominal pain were noticed. Fecal shape and consistency were back to normal on day 7. The stent bandage and skin sutures were removed on day 1 and 14, respectively. Radiographic monitoring of the fracture site performed on the immediate postoperative period revealed no abnormalities (Fig.2). The horse was discharged two months after surgery. The owner was recommended to keep the horse at rest in a small paddock for 
additional 3 months. Re-evaluation performed 6 months after discharge showed that the horse was sound and back to the previous function. Followup information obtained by direct conversation with the owner 10 years later revealed that the horse remained sound on the operated leg and performed his job well for additional 7 years until his death. The horse died for causes unrelated to the fracture.

\section{Discussion}

Olecranon fractures are among the most common long bone fractures in horses. The cause of the fracture is associated with direct trauma usually produced by a kick or a fall (RICHARDSON, 2000; WATKINS, 2006). Other reported causes of trauma include horse fights, hit by vehicle, caught in fencing and difficult anesthetic recovery (SWOR et al., 2006). In the case reported here the origin of the trauma was unknown but either a kick, fall, horse fight or hit by vehicle might be possible explanations.

The characteristic position of semi-flexed carpus and fetlock and "drooped elbow" adopted by many horses with olecranon fractures is explained by the disruption of the triceps brachii muscle. The triceps muscle inserts on the olecranon process. Upward traction of the olecranon produced by the triceps contraction extends the elbow joint. When the elbow is extended, the other joints of the forelimb are passively fixed in the weight bearing position by the stay apparatus. Therefore, the ability of the horse to fully extend the forelimb and fix it in the weight bearing position relies on the integrity of the olecranon. Although the "dropped elbow" is a well known clinical sign of horses with olecranon fractures, care should be exercised to differentiate it from other conditions such as radial nerve paralysis and humeral fractures based solely on the clinical presentation (NIXON, 1996; WATKINS, 1999, 2006).

Olecranon fractures can be presented in various configurations and different classifications have been proposed. (DONECKER; BRAMLAGE; GABEL, 1984; WILSON; RIEDESEL, 1985; NIXON, 1996; STASHAK, 2002b). Fackelman (2000) categorized olecranon fractures into five different types (Fig.3). The fracture sustained by the horse reported here approaches closely to a type-5 olecranon fracture which, by definition, is a distal olecranon-proximal ulnar fracture, which usually have an oblique configuration traversing the bone in a proximal and cranial direction to enter the distal aspect of the trochlear notch (WATKINS, 2006).

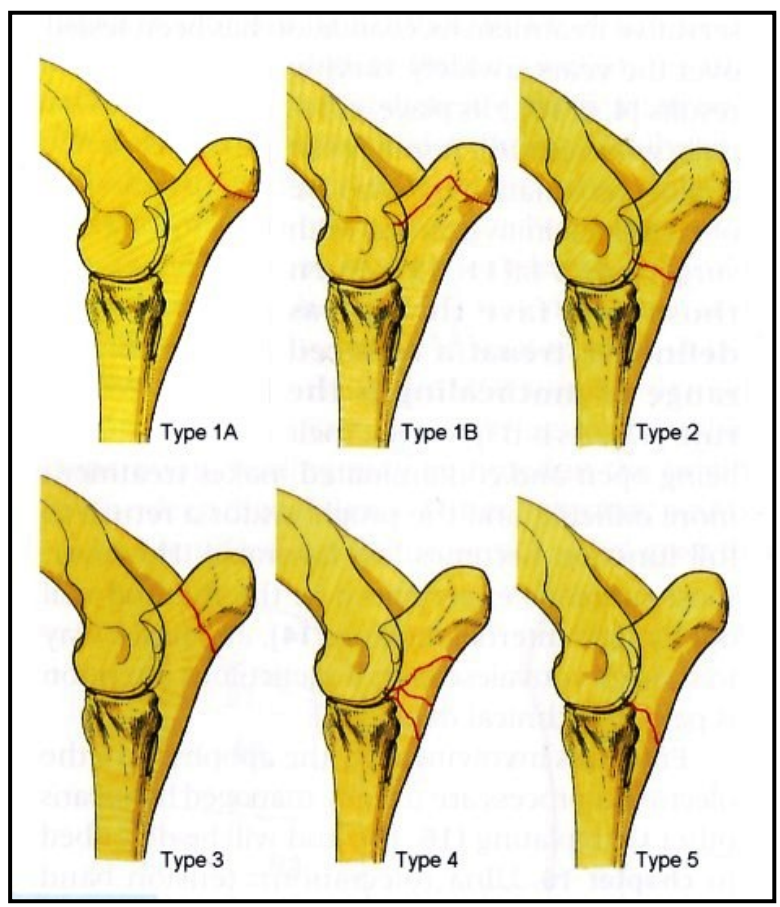

Figure 3. Classification of olecranon fractures. Modified with permission from (FACKELMAN, 2000).

Controversy exists among authors in regard to the most common type of olecranon fracture. Whereas type-2 olecranon fractures have been reported as the most common fracture by Donecker, Bramlage and Gabel (1984); Denny, Barr and Waterman (1987); Denny (1989) and Martin et al. (1995), another description indicates type-1B as the most common (WATKINS, 2006). Furthermore, in a more recent study, type-4 (comminuted) olecranon fractures were the most prevalent (JANICEK et al., 2006). 
It has been reported that intraoperative reduction of the fracture can be accomplished by full extension of the elbow and consequent release of the triceps pulling action (JOHNSON; BUTLER, 1971; MCGILL; HILBERT; JACOBS, 1982; DENNY, 1989). Despite several attempts to extent the elbow and manipulate the fracture site, anatomic reduction of the fracture was not achieved. Failure to reduce the fracture by means of extension and manipulation maneuvers might have been caused by severe and prolonged contraction of the triceps brachii muscle as a result of the time elapsed between the accident and the surgery (i.e. 16 days). The degree of distraction between the fragments precluded anatomic apposition even after interfragmentary compression exerted by the plate. A better reduction of the fracture might have been accomplished with the aid of the tension device (MCILWRAITH; ROBERTSON, 1998); therefore preventing or minimizing the fracture gap.

Fracture gap formation should always be avoided during surgical repair of fractures, especially when dealing with articular fractures. In cases of articular fractures accurate anatomic reduction to prevent joint surface incongruity and rigid fixation of the fragments to promote primary bone healing are the ultimate goals to restore normal articular function. Despite the articular component of the fracture the prognosis was not negatively influenced by the fracture gap. This observation is in agreement with two retrospective studies of 44 horses treated by plating for correction of type 1B (24 horses) (SWOR et al., 2003) and type-5 (20 horses) (SWOR et al., 2006) olecranon fractures. In those studies, involvement of the joint or mild gaps or steps at the distal semilunar notch post surgery did not appear to affect prognosis. Based on these observations, Swor et al. (2003, 2006) stated that this particular joint seems to be tolerant of imperfections to a certain extent. Moreover, it is interest to point out that fractures located at the very distal aspect of the semilunar notch break into the synovial fossa present at that location rather than in the articular cartilage (SWOR et al., 2006; WATKINS, 2006). Perhaps, this fact may somehow explain why fractures located at the distal semilunar notch may heal favorably despite some imperfections.

In order to provide a stronger fixation of the fracture by increasing the purchase of the screws in a greater area of cortical bone, the distal screws of the plate were engaged in the caudal cortex of the radius. Because of the high bone density of the radius in the mature horse the distal screws were only engaged in the caudal cortex (TURNER, 1983; MCILWRAITH; ROBERTSON, 1998). Fixation of the ulna to the radius during plating of olecranon fractures in mature horses has no untoward effects. However, radioulnar fixation in foals undergoing plating for repair of olecranon fractures has been responsible for different degrees of elbow displasia and humeroulnar subluxation (CLEM et al., 1988).

The two holes of the plate adjacent to the fracture line were left void. This was not detrimental to the stability of the fixation since the major force applied to the plate in this case is a tensile force as oppose to compression, shear, rotational and bending forces commonly present in fixation of long bone fractures (TURNER, 1983; MARKEL, 1996). Ideally, at least three screws proximal and four screws distal to the fracture should be inserted to provide adequate fixation (NIXON, 1996). The screw placed immediately above the fracture was shorter than ideal and angled proximally. A longer, properly angled screw should have been used to provide better purchase on the parent bone and thus, strengthen the fixation. In order to assist in the selection of implants, a careful surgical plan should be sketched on preoperative radiographs. This procedure not only permits a good estimate of location, direction, number and length of screws to be used but also provide spatial knowledge of the anatomic landmarks related to the fracture. Special attention should be paid to the correct placement of proximal screws on the olecranon process. Due to the medial concavity of the olecranon, inadequately placed screws may impinge on the medial humeral 
epicondyle with consequent bending (DENNY; BARR; WATERMAN, 1987; FACKELMAN, 2000). In addition, care should be taken not to advance into the joint during perforation and screw placement.

The plate was bent and contoured to fit the caudal aspect of the ulna using bending irons. This procedure was time consuming and labor intensive. Plate bending would have been expedited had the plate-bending press been used. Removal of the posterior ridge of the ulna to better seat the plate on the caudal aspect of the olecranon has been described (FRETZ, 1973). In this case, this technique was not performed due to the relatively low concavity and satisfactory seat of the plate on the caudal aspect of the olecranon. The plate used to repair the fracture in the case reported here was a narrow DCP. Currently, the standard DCP is being replaced by new-developed plate models such as the low contact dynamic compression plate (LC-DCP). The LC-DCP has been used not only to repair olecranon fractures but in equine orthopedic surgery in general with numerous advantages over the standard DCP (AUER, 2006).

Treatment selection for cases of olecranon fractures is dictated by the configuration of the fracture, its level at the olecranon in relation to the radiohumeral articulation and the age and weight of the horse (RICHARDSON, 1990, 2000; NIXON, 1996; STASHAK, 2002b; WATKINS, 2006). An overall poor prognosis for recovery has been shown after nonsurgical treatment of ulnar fractures (WILSON; RIEDESEL, 1985). Therefore, nonsurgical treatment (i.e. stall rest and full-limb splinting) has only been recommended for nonarticular/nondisplaced fractures (DONECKER; BRAMLAGE; GABEL, 1984; DENNY; BARR; WATERMAN, 1987). Although nonsurgical treatment has been an affordable and successful option for treatment of nonarticular/nondisplaced fractures decreased convalescence period and improved level of comfort can be attained by treating theses cases surgically (WATKINS, 1999).
Several reports describe the benefits and the excellent results obtained with open reduction and internal fixation of olecranon fractures (MCGILL; HILBERT; JACOBS, 1982; DONECKER; BRAMLAGE; GABEL, 1984; DENNY; BARR; WATERMAN, 1987; ANDERSON; ALLEN; DEBOWES, 1995; SCOTT et al., 1998; SWOR et al., 2003, 2006; JANICEK et al., 2006). A retrospective study of 29 olecranon fractures surgically repaired with a tension band plate revealed a success rate of $68 \%$, with $84 \%$ of these horses returning to athletic function (DONECKER; BRAMLAGE; GABEL, 1984). In another study of 21 cases of olecranon fractures also treated with tension band plating, 76\% of the horses regained full limb function (DENNY; BARR; WATERMAN, 1987). In both studies, type-2 fractures were the most common configuration. In addition, a recent report describing the racing prognosis for horses undergoing internal fixation of olecranon fractures by different methods of stabilization (i.e. DCP, hook plate and tension band wires) has shown an overall favorable prognosis for racing, being the DCP the most commonly employed method of repair (JANICEK et al., 2006). A more recent series of type-5 olecranon fractures in 20 horses treated surgically by plate fixation has shown that 13 of the 15 horses $(87 \%)$ of which longterm follow up was available returned to athletic use or were in training (SWOR et al., 2006).

Successful surgical repair of olecranon fractures is best accomplished with rigid stabilization of the fracture using a tension band plate fixation applied to the caudal aspect of the ulna (MCGILL; HILBERT; JACOBS, 1982; TURNER, 1983; JANICEK et al., 2006). An in vitro study designed to compare three different techniques of surgical stabilization of olecranon fractures has shown the DCP as the strongest method of repair (HANSON; HARTWIG; MARKEL, 1997). The main goal of surgical management is to counteract the distracting forces of the triceps-olecranon apparatus. Almost all types of olecranon fractures are amenable to plate fixation. The only exception is the type-1A (physeal) fracture, 
where the small proximal fragment of the fracture may preclude plate application (MCILWRAITH; ROBERTSON, 1998).

Despite the stormy recovery the fracture fixation was not jeopardized as shown by the postoperative radiograph. Catastrophic failure of the implants has not occurred owing to the strong fixation provided by the plate, the non-weight bearing function of the ulna and the primary force withstood by the plate (i.e. tension).

Surgical repair of olecranon fractures with tension band plating rarely requires implant removal (FACKELMAN, 2000). In mature animals, the main indications for plate removal include infection and performance limitations in athletes associated with the fixation (DENNY, 1989; RICHARDSON, 1990; NIXON, 1996). In this case, the implants were left in situ based primarily on the complete soundness achieved by the horse post-operatively.

This article describes the surgical repair of an olecranon fracture in an adult horse using the tension-band principle (JOHNSON; BUTLER, 1971) of fracture fixation by means of application of a DCP. Knowledge of the basic orthopedic principles of plate and screws placement, the biomechanical forces related to the fracture and the regional anatomy are essentials to successfully perform the surgery. In agreement with other authors (SWOR et al., 2006) the prognosis for returning to complete soundness following tension band plate fixation of type-5 olecranon fractures is good.

\section{References}

ANDERSON, D. E.; ALLEN, D.; DEBOWES, R. M. Comminuted, articular fractures of the olecranon process in horses: 17 cases (1980 to 1990). Veterinary and Comparative Orthopaedics and Traumatology, New York, v. 8, n. 3, p. 141-145, 1995.

AUER, J. A. Principles of fracture treatment. In: AUER, J. A.; STICK, J. A. Equine surgery. $3^{\text {th }}$ ed. Philadelphia: W.B.Saunders Company, 2006. p. 1001-1029.
CLEM, M. F.; DEBOWES, R. M.; DOUGLASS, J. P.; LEIPOLD, H. W.; CHALMAN, J. A. The effects of fixation of the ulna to the radius in young foals. Veterinary Surgery, Philadelphia, v. 17, n. 6, p. 338-345, 1988.

DENNY, H. R. Fractures of the olecranon and ulna shaft. In: _. Treatment of equine fractures. London: Wright, 1989. p. 34-56.

DENNY, H. R.; BARR, A. R. S.; WATERMAN, A. Surgical treatment of fractures of the olecranon in the horse: A comparative review of 25 cases. Equine Veterinary Journal, London, v. 19, n. 4, p. 319-325, 1987.

DONECKER, J. M.; BRAMLAGE, L. R.; GABEL, A. A. Retrospective analysis of 29 fractures of the olecranon process of the equine ulna. Journal of the American Veterinary Medical Association, Schaumburg, v. 185, n. 2, p. 183-189, 1984.

FACKELMAN, G. E. Ulna (olecranon): plate fixation. In: FACKELMAN, G. E.; NUNAMAKER, G. M.; AUER, J. A. A O Principles of equine osteosynthesis. New York: Thieme, 2000. p. 159-169.

FRETZ, P. B. Fractured ulna in the horse. Canadian Veterinary Journal, Ottawa, v. 14, n. 2, p. 50-53, 1973.

HANSON, P. D.; HARTWIG, H.; MARKEL, M. D. Comparison of three methods of ulnar fixation in horses. Veterinary Surgery, Philadelphia, v. 26, n. 3, p. 165-171, 1997.

JANICEK, J. C.; RODGERSON, D. H.; HUNT, R. J.; SPIRITO, M. A.; THORPE. P. E.; TESSMAN, R. K. Racing prognosis of horses following surgically repaired olecranon fractures. Canadian Veterinary Journal, Ottawa, v. 47, n. 3, p. 241-245, 2006.

JOHNSON, J. H.; BUTLER, H. C. The tension-band principle in fixation of an equine ulnar fracture. Veterinary Medicine Small Animal Clinician, Bonner Springs, v. 66, n. 6, p. 552-556, 1971.

MARKEL, M. D. Fracture biomechanics. In: NIXON, A. J. Equine fracture repair. Pennsylvania: W.B.Saunders, 1996. p. 10-18.

MARTIN, F.; RICHARDSON, D. W.; NUNAMAKER, D. M.; ROSS, M. W.; ORSINI, J. A. Use of tension band wires in horses with fractures of the ulna: 22 cases (19801992). Journal of the American Veterinary Medical Association, Schaumburg, v. 207, n. 8, p. 1085-1089, 1995.

MCGILL, C. A.; HILBERT, B. J.; JACOBS, K. V. Internal fixation of fractures of the ulna in the horse. Australian Veterinary Journal, Brunswick, v. 58, n. 3, p. 101-104, 1982. 
MCILWRAITH, C. W.; ROBERTSON, J. T. McIlwraith \& Turner's equine surgery: advanced techniques. Baltimore: Williams \& Wilkins, 1998. 440 p. cap. 5.

MILNE, D. W.; TURNER, A. S. Abordagem da face caudal e lateral da ulna e do olécrano. In: Atlas das abordagens cirúrgicas dos ossos do cavalo. São Paulo: Roca, 1987. p. 92-96.

MONIN, T. Repair of physeal fractures of the tuber olecranon in the horse, using a tension band method. Journal of the American Veterinary Medical Association, Schaumburg, v. 172, n. 3, p. 287-290, 1978.

MURRAY, R. C.; DEBOWES, R. M.; GAUGHAN, E. M.; BRAMLAGE, L. R. Application of a hook plate for management of equine ulnar fractures. Veterinary Surgery, Philadelphia, v. 25, n. 3, p. 207-212, 1996.

NIXON, A. J. Fractures of the ulna. In: Equine frature repair. Philadelphia: W. B. Saunders Company,1996. p. 231-241.

NIXON, A. J.; WATKINS, J. P.; AUER, J. A. Principles of fracture fixation. In: NIXON, A. J. Equine frature repair. Philadelphia: W.B. Saunders Company, 1996. p. 63-86.

RICHARDSON, D. W. Ulnar fractures. In: WHITE, N. M.; MOORE, J. N. Current practice of equine surgery. Philadelphia: J. B. Lippincott Company, 1990. p. 641646.

RICHARDSON, D. W. Ulna (olecranon): tension band wiring. In: FACKELMAN, G. E.; NUNAMAKER, G. M.; AUER, J. A. A. O. Principles of equine osteosynthesis. New York: Thieme, 2000. p. 171-177.

SCOTT, E. A.; MATTOON, J. S.; ADAMS J. G.; RIEBOLD, T. W.; TESHERA, J. Surgical repair of bilateral comminuted articular ulnar fractures in a sevenmonth-old horse. Journal of the American Veterinary Medical Association, Schaumburg, v. 212, n. 9, p. 13801383, 1998.

STASHAK, T. S. Examination for lameness. In: Adams' lameness in horses. $5^{\text {th }}$ ed. Baltimore: Lippincott Williams \& Wilkins, 2002a. cap. 3, p.113-183.

STASHAK, T. S. Fractures of the ulna. In: Adams' lameness in horses. $5^{\text {th }}$ ed. Baltimore: Lippincott Williams \& Wilkins, 2002b. cap. 8, p. 879-894.

SWOR, T. M.; WATKINS, J. P.; BAHR, A.; EPSTEIN, K. L.; HONNAS, C. M. Results of plate fixation of type 5 olecranon fractures in 20 horses. Equine Veterinary Journal, London, v. 38, n. 1, p. 30-34, 2006.

SWOR, T. M.; WATKINS, J. P.; BAHR, A.; HONNAS, C. M. Results of plate fixation of type $1 \mathrm{~b}$ olecranon fractures in 24 horses. Equine Veterinary Journal, London, v. 35, n. 7 , p. $670-675,2003$.

TURNER, A. S. Fractures of the olecranon. Veterinary Clinics of North America, Philadelphia, v. 5, n. 2, p. 275283, 1983.

WATKINS, J. P. Ulnar fractures. In: COLAHAN, P.; MAYHEW, I. G.; MERRIT, A. M.; MOORE, J. N. Equine medicine and surgery. $5^{\text {th }}$ ed. St. Louis: Mosby, 1999. p. 1648-1652.

WATKINS, J. P. The radius and ulna. In: AUER, J. A.; STICK, J. A. Equine surgery. $3^{\text {th }}$ ed. Philadelphia: W.B.Saunders Company, 2006. p. 1267-1279.

WILSON,D.G.; RIEDESEL,E. Nonsurgicalmanagement of ulnar fractures in the horse. A retrospective study of 43 cases. Veterinary Surgery, Philadelphia, v. 14, n. 4, p. 283-286, 1985. 